\title{
Radioimmunotherapy in Head and Neck Cancer
}

\author{
Ik Joon Choi \\ Department of Otorhinolaryngology-Head and Neck Surgery, Korea Cancer Center Hospital, Seoul, Korea
}

\section{두경부암에서 방사면역치료의 역할}

\author{
최 익 준 \\ 원자력병원 이비인후과
}

\author{
Received October 27, 2018 \\ Revised November 12, 2018 \\ Accepted November 19, 2018 \\ Address for correspondence \\ Ik Joon Choi, MD, PhD \\ Department of Otorhinolaryngology- \\ Head and Neck Surgery, \\ Korea Cancer Center Hospital, \\ 75 Sanggye-ro, Nowon-gu, \\ Seoul 01693, Korea \\ Tel $+82-2-970-1271$ \\ Fax $+82-2-970-2450$ \\ E-mail ijchoiorl@gmail.com
}

Radioimmunotherapy (RIT) is a therapy that takes advantage of the "cross-fire" effect of emitted radiation by radionuclides conjugated to tumor-directed monoclonal antibodies $(\mathrm{mAb})$ (including those fragments) or peptides. While RIT has been successfully employed for the treatment of lymphoma, mostly with radiolabeled antibodies against CD20 $\left[{ }^{90}\right.$ yttrium $\left({ }^{90} \mathrm{Y}\right)$ ibritumomab tiuxetan; Zevalin ${ }^{\mathbb{R}}$ and ${ }^{131}$ iodine $\left({ }^{131} \mathrm{I}\right)$-tositumomab; Bexxar ${ }^{\mathbb{R}}$ ], its use in solid tumors is more challenging, so far. Immuno-PET, a tool for tracking and quantification of mAbs with PET in vivo, is an exciting novel option to improve diagnostic imaging and guide $\mathrm{mAb}$ based therapy. RIT in solid tumors including head and neck cancer may be an alternative treatment with advances in various biological, chemical, and treatment procedures, and it may help to reduce unnecessary exposure and enhance the therapeutic efficacy. Also, immuno-PET based on RIT might play an important role in cancer staging, in patients or targets selection of targeted therapeutics and in monitoring the response of targeted therapeutics as precision medicine. In this review, fundamentals of RIT/immune-PET and current knowledge of the preclinical/ clinical trials in RIT for solid tumor including head and neck cancer are reviewed. Korean J Otorhinolaryngol-Head Neck Surg 2018;61(12):637-43

Key Words Head and neck · Monoclonal antibody · Radioimmunotherapy $\cdot$ Radioisotope Squamous cell carcinoma.

\section{서 론}

두경부 편평상피세포 암종(head and neck squamous cell carcinoma, $\mathrm{HNSCC}$ )은 일곱 번째 가장 흔한 암으로 연간 전 세계적으로 60 만 건 이상의 발생률을 보인다. ${ }^{1)}$ 두경부암은 조기암이나 국소 진행암의 경우 치료 성적에 있어 괄목할만 한 발전이 있었지만 재발하였거나 원격전이를 동반한 경우에 는 치료 성적이 과거에 비해 현저히 개선되었다고 말하기 어 렵다. 최근 분자생물학적 기법과 지식이 눈부시게 발전하면 서 암치료에 있어서도 특정 분자를 표적으로 하는 치료, 이른

This is an Open Access article distributed under the terms of the Creative Commons Attribution Non-Commercial License (https://creativecommons.org/licenses/by-nc/4.0) which permits unrestricted non-commercial use, distribution, and reproduction in any medium, provided the original work is properly cited.
바 분자 표적 암치료(molecular targeted cancer therapy)에 대한 기대가 높아지고 있다.

표피 성장인자 수용체(epidermal growth factor receptor, EGFR)는 두경부암을 포함한 여러 암종에서 가장 연구가 많 이 진행된 표적인자 중에 하나로 두경부암에서는 $90 \%$ 이상에 서 과발현된다는 점에서 임상적으로 중요하게 여겨져 왔다. ${ }^{2,3)}$

$\mathrm{EGFR}$ 과발현은 나쁜 예후, 종양 성장의 증가, 전이, 화학 요법 및 방사선 요법에 대한 내성과 관련이 있는 것으로 알려 져 있는데 아직까지 소분자 티로신 키나아제 억제제나 EGFR 에 대한 단일클론항체, cetuximab 및 panitumumab에 의한 단독 요법은 두경부암에서 효과가 제한적이다. ${ }^{4-7)}$ 따라서 두 경부암 환자에서 약물 저항성과 제한된 반응률을 극복하기 위해서는 대체 치료법이 필요하다. 그중 하나가 방사면역치료 
(radioimmunotherapy, RIT)가 될 수 있다.

\section{방사면역치료의 항암 기전}

방사면역치료는 항체 의존성 세포독성(antibody dependent cellular cytotoxicity) 및 보체 의존성 세포독성(complement dependent cytotoxicity) 기전을 이용한 기존의 단백면역항체 에 의한 면역치료효과에 항체에 접합된 방사성 동위원소에 서 방출되는 방사선에 의한 "cross-fire" 효과를 이용하는 치 료법이다. 많은 전임상 및 임상연구를 통해서 방사성 면역 접 합체(radioimmunoconjugate)(방사성 동위원소로 표지된 항 체)를 이용한 면역치료가 비접합 항체를 이용한 단독 면역치 료 요법보다 임상적으로 유의하게 뛰어난 치료 효과를 보이 는 것이 보고되어져 왔다. ${ }^{8-10)}$

방사면역치료는 면역 단백질을 방사능의 운반자, 추적자 또는 표적 치료제로 이용한다. 방사선 면역 접합체는 종양, 흥막 주위 또는 흥막강과 같은 체강 내로 직접 주사되거나 정맥 내로 주입되고, 일단 주입되면 방사성 항체는 혈류, 확 산 또는 대류에 의해 종양세포 상의 항원-결합 부위에 분포 하게 되면서 방사성 핵종의 붕괴 중에 발생하는 엄청난 에너 지 방출로 인한 방사선 효과로 종양에 대량의 살균 선량을 전 달해서 치료 효과를 나타나게 된다(Fig. 1).

임상적으로 RIT는 그동안 방사선 민감성 종양, 특히 비호 지킨 림프종(Non Hodgkin's lymphoma, NHL) 치료에 있어 엄청난 성공을 거두어 왔고, 그 결과 $\mathrm{CD}-20$ 발현 $\mathrm{B}$ 세포 림프 종에서 ${ }^{90}$ yttrium ${ }^{90} \mathrm{Y}$ ) 표지 ibritumomab tiuxetan(Zevalin ${ }^{\circledR}$ ) 과 ${ }^{131}$ iodine $\left({ }^{(131} \mathrm{I}\right)$ 표지 tositumomab $\left(\mathrm{Bexxar}^{\circledR}\right)$ 가 현재 FDA

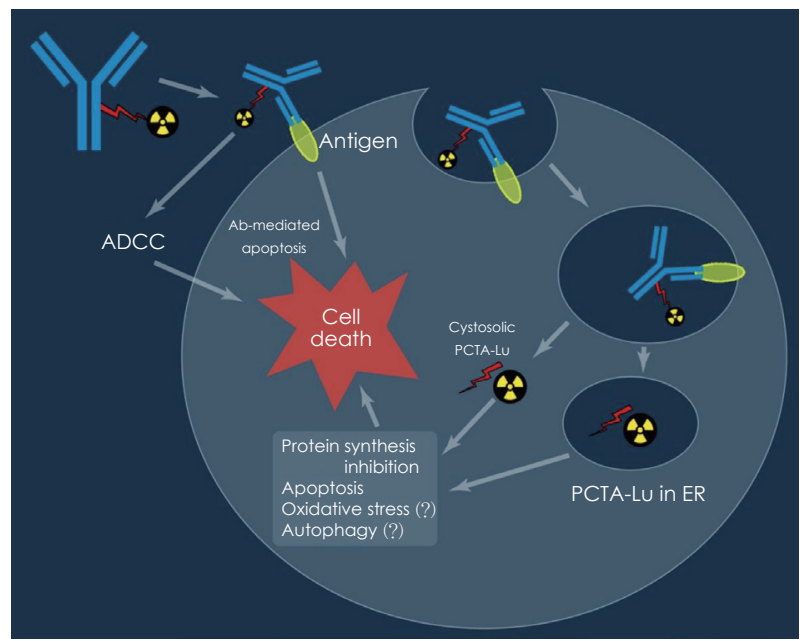

Fig. 1. Scheme of radioimmunotherapy, cell death induced by ADCC \& internalization of radioimmunoconjugate. ADCC: antibody dependent cellular cytotoxicity, PCTA: 3, 6, 9, 15-tetraazabicyclo [9.3.1] pentadeca-1(15), 11, 13 triene 3, 5, 9-triacetic acid, Lu: lutetium, ER: endoplasmic reticulum.
승인을 받아서 임상 적용이 되고 있다.

\section{고형암에서의 방사면역치료}

혈액암 및 림프종에서 방사면역치료의 뛰어난 치료 효과로 인해서 임상 적용이 활발한 반면에 그동안 고형암에서의 RIT 의 치료 효과는 임상적으로 제한적이었다.11

두경부암, 유방암, 난소암, 대장암, 전립선암, 신장암 및 뇌 암을 비롯한 다양한 종류의 고형 종양을 치료하기 위해 수많 은 방사성 표지 항체가 개발 중에 있다(Table 1). 이러한 모 든 방사성 표지 항체는 두 가지 치료 요소, 즉 방사선에 의한 치료 효과 및 항원 항체 결합 시 항체에 의한 작용을 통해 암세포를 죽일 잠재력을 가지고 있다. 방사선에 의한 암세포 사멸은 주로 DNA 손상에 의한 것으로 암세포에 방사선이 조사되면 DNA 단일 가닥 절단(single-strand break)과 이중 가닥 절단(double-strand break)이 발생된다. 방사선에 의한 세포 사멸이 우세한 방사선 감수성 NHL과 비교할 때, 대부 분의 고형 종양은 방사선 조사 후에 세포자멸사를 거의 보이 지 않는다. 결과적으로 방사선 민감성 NHL에 비해 고형 종양 을 죽이기 위해서는 훨씬 높은 방사선량이 필요하다. 이는 고 형암 발생의 기원 세포가 상대적으로 혈액암에 비해서 방사선 저항성이 높은 특성에 기인한다. 여러 연구 보고를 통해 전립 선암(64.8 81 Gy), ${ }^{12)}$ 폐암(40 65 Gy), ${ }^{13)}$ 신경아교종 $(60 \mathrm{~Gy}),{ }^{14)}$ 대장암 $(70 \mathrm{~Gy})^{15)}$ 과 같은 고형 종양에서 임상 반응을 얻기 위 해서는 최소한 방사선량이 $50 \mathrm{~Gy}$ 에 도달해야 하는데 고형 종양에서 보고된 대부분의 방사면역치료에 대한 연구에서 종양에 도달한 방사선량은 $50 \mathrm{~Gy}$ 이하로 보고된다. 이런 치 료 효과의 제한점을 극복하고 조직의 고유 방사선 민감도에 관계없이 RIT의 치료 효과를 높이는 방법은 높은 방사선량을 종양에 안전하게 전달하는 가장 효율적인 방법을 개발하는 것이고 또한 암세포 성장 및 생존에 중요한 종양 항원을 발굴 하고 표적으로 하는 것이다.

또한 의미 있는 종양 흡수선량을 얻기 위해 높은 국소 방사 능 농도를 전달할 수 있는 대안으로 방사성 표지 항체를 종양 주위에 국지적으로 주사하는 방법에 대한 연구가 진행되어 져 왔고 또 다른 접근법으로는 알파 입자와 같이 비교적 높은 생물학적 효과(relative biological effectiveness)를 갖는 입 자 방출(particle emission)을 사용하는 방법이 연구되어왔다. 알파 입자는 짧은 경로를 따라 매우 높은 에너지를 축적할 수 있어서 기존에 많은 연구가 된 베타 입자보다 선형 에너지 전달이 2 3배 더 높은 것으로 알려져 있다. ${ }^{16)}$

방사성 표지 항체를 이용한 RIT에서는 일반적으로 적색 골 수에 대한 독성 때문에 단독 항체를 이용한 면역치료 때 보 
Table 1. Tumor surface antigens which are targeted in clinical trials of solid tumor radioimmunotherapy

\begin{tabular}{|c|c|c|c|c|}
\hline Antigens & Phases & Cancer types & Radiolabeled mAbs & Combination \\
\hline \multirow[t]{6}{*}{ CEA } & 1 & Colorectal cancer & cT84.66- ${ }^{90} \mathrm{Y}$ & Floxuridine, gemcitabine \\
\hline & । & NSCLC & cT84.66- ${ }^{90} \mathrm{Y}$ & Carboplatin, paclitaxel, radiation \\
\hline & । & Colorectal cancer & TF2+IMP-288- ${ }^{177} \mathrm{LU}$ & No \\
\hline & । & Colorectal cancer & TF2+|MP-288- ${ }^{\mid 31} \mid$ & No \\
\hline & $\|$ & Medullary thyroid carcinoma & F6-734+di-DTPA- ${ }^{\mid 31} \mid$ & No \\
\hline & । & CEA producing tumors & $M 5 A-{ }^{90} Y$ & No \\
\hline \multirow[t]{6}{*}{ PSMA } & । & Prostate cancer & HuJ591-177LU & No \\
\hline & $\|$ & Prostate cancer & HuJ591-177LU & No \\
\hline & । & Prostate cancer & HuJ591-177LU & Docetaxel, prednisone \\
\hline & $\|$ & Prostate cancer & HuJ591-177Lu & Ketoconazole, hydrocortisone \\
\hline & I & Non-prostate solid tumors & HuJ591- ${ }^{177} \mathrm{Lu}$ & No \\
\hline & । & Prostate cancer & 7E11-C5.3- ${ }^{177} \mathrm{Lu}$ & No \\
\hline Tenascin-C & ॥ & Glioblastoma multiforme & $81 \mathrm{Cb}^{-131}$ & Bevacizumab \\
\hline \multirow[t]{3}{*}{ GD2 } & I & Neuroblastoma & $3 F 8-{ }^{131} \mid$ & Bevacizumab, filgrastim \\
\hline & $\|$ & Brain tumors & $3 F 8-{ }^{131} \mid$ & No \\
\hline & $\|$ & Medulloblastoma & $3 F 8^{-131} \mid$ & Lomustine, vincristine, IMRT \\
\hline $4 \lg -\mathrm{B} 7-\mathrm{H} 3$ & । & Brain tumors & $8 \mathrm{H} 9-^{131} \mathrm{I}$ & No \\
\hline \multirow[t]{2}{*}{ CAIX/MN } & । & Renal cell carcinoma & $c G 250-{ }^{90} Y$ & No \\
\hline & $|/| \mid$ & Renal cell carcinoma & CG250- ${ }^{177} \mathrm{Lu}$ & No \\
\hline MUCl & । & Pancreatic cancer & hPAM4-90Y & Gemcitabine \\
\hline DNA/histone $\mathrm{HI}$ (necrosis) & $\|$ & Glioblastoma multiforme & ChTNT-1/B- ${ }^{131}$ & No \\
\hline EGFR & $\|$ & Glioma & $425^{-25}$ & No \\
\hline Melanin & । & Melanoma & PTI-6D2- ${ }^{188} \operatorname{Re}$ & No \\
\hline
\end{tabular}

Adapted from Song and Sgouros. Curr Drug Deliv 201 1;8(1):26-44. ${ }^{17)}$ CEA: carcinoembryonic antigen, NSCLC: non-small cell lung carcinoma, PSMA: prostate-specific membrane antigen, GD2: ganglioside 2, CAIX/MN: carbonic anhydrase IX, EGFR: epidermal growth factor receptor, MUC1: mucin 1, IMRT: intensity-modulated radiation therapy, Y: yttrium, Lu: lutetium, I: iodine, Re: rhenium

다 항체의 양을 단일 또는 분획 투여 계획으로 소량을 사용 하여 투여하게 된다. 대장암에서 항 EGFR 항체 cetuximab 을 이용한 단독 항체면역치료에서 치료 기간 동안 초기에 체 표면적당 $400 \mathrm{mg} / \mathrm{m}^{2}$ (남성의 경우 평균 $1.9 \mathrm{~m}^{2}$ )의 항체를 주 사하고 이후에 매주 $250 \mathrm{mg} / \mathrm{m}^{2}$ 로 주사한 반면에, ${ }^{18)}$ 항 $\mathrm{EGFR}$ 항체 방사면역치료에 대한 임상 연구에서는 $3.2 ~ 3.4 \mathrm{mg}$ 의 항 체를 3회 분획 주사하여 단독 항체면역치료와 비교하여 100 배 이상 적은 양을 이용하였다. ${ }^{19)}$ RIT에 사용되는 항체의 양 이 적게 되면 혈류의 감소, 간질 압력의 증가 및 이종 항원 발 현 등으로 인하여 치료 효과가 떨어질 수 있는 제한점이 있 어서 이를 극복하기 위하여 대량의 항체를 먼저 투여하고 이 미 결합된 항체에 결합할 수 있는 방사성 표지 소분자 치료 제를 투여하는 방법도 연구가 되어지고 있다. ${ }^{20}$

\section{EGFR 발현 두경부암에서 ${ }^{177} \mathrm{Lu}$ 표지 항 EGFR 단일클론항체를 이용한 방사면역치료}

Cetuximab은 chimeric anti-EGFR IgG1으로 높은 친화
력으로 $\mathrm{EGFR}$ 에 결합하고, 다운 스트림 신호 전달 경로의 활성화를 방지하며 항체 의존성 세포 독성을 유도하는 작용 으로 HNSCC 환자 치료를 위해 FDA에 의해 승인되었다. 하 지만 cetuximab을 단일 약제로 사용하는 경우 내인성 및 후 천성 약물 내성으로 인하여 EGFR 표적 치료법에 대한 결과 가 예상과는 달리 좋지 않은 것이 현실이다. 따라서 HNSCC 환자에서 약물 저항성과 제한된 반응률을 극복하기 위해서는 대체 치료법이 필요하다. 비록 다양한 억제제에 의한 EGFR 억제가 고형 종양에서 치유되지는 않을지라도, 방사선 요법과 의 병용 접근은 국소 종양 조절을 적당히 개선할 수 있는 것 으로 알려져 있다. ${ }^{21,22)}$

최근 여러 연구에서 면역 양전자방출단층촬영(immunoPET) 제제로 방사성 표지 항 EGFR 항체를 사용하여 표적 발 현의 정확한 정량화 및 방사면역요법제로서의 치료 효능을 증 대할 수 있음을 보여 주었다. ${ }^{8)}$

현재까지 HNSCC 모델의 RIT에 사용되는 가장 일반적인 방사성 핵종은 ${ }^{90} \mathrm{Y}$ 와 ${ }^{177}$ lutetium $\left({ }^{177} \mathrm{Lu}\right)$ 이다(Table 2). 이 두 가 지 방사성 핵종은 RIT의 효과에 기여하는 중요한 요소인 방 출 특성과 화학적 안정성의 차이 때문에 각각의 장단점이 있 
다. ${ }^{90} \mathrm{Y}$ 의 이점은 종양에 더 높은 베타 에너지를 전달한다는 것(2.3 MeV vs. ${ }^{177} \mathrm{Lu}$ 의 경우 $\left.0.61 \mathrm{MeV}\right)$ 과 방출된 에너지의 $90 \%$ 이상이 흡수되는 평균 깊이가 더 깊다 $\left(5.3 \mathrm{~mm}\right.$ vs. ${ }^{177} \mathrm{Lu}$ 의 경우 $0.8 \mathrm{~mm})$. 이러한 특성은 표적 세포와 이웃 세포 모두 를 죽이는 방사성 표지 항체의 능력을 향상시키며, 이것은 부 피가 크거나 혈관이 형성되지 않은 종양이 있을 때 특히 중요 한 것으로 알려져 있다. 또한 ${ }^{90} \mathrm{Y}$ 는 순수 베타 방출 방사성 동 위원소이기 때문에 입원, 격리 또는 차폐가 필요하지 않으며 환자는 외래 환자로 치료받을 수 있는 장점이 있다. 하지만 매 우 비싸고 감마선을 방출하지 않으므로 이미지에 사용할 수 없는 단점이 있다. ${ }^{23)}$

${ }^{177} \mathrm{Lu}$ 의 장점은 ${ }^{90} \mathrm{Y}$ 와 비교하여 상업적으로 이용 가능하고 항체에 쉽게 접합되며 오랜 역사를 가지고 있다는 점이고 의 료적 사용에 안전하고 또한 감마 에너지를 방출하기 때문에 이미지에 사용할 수 있다는 점이 유리하다. 하지만 ${ }^{177} \mathrm{Lu}$ 의 사 용은 차폐를 통한 입원이 필요하고 원거리 기관에 방사선이 조사될 수 있는 단점이 있다. 표적화된 분자에 금속 방사성 동위원소를 부착시키기 위해서는 일반적으로 이원성 킬레이 트(bifunctional chelate, $\mathrm{BFC}$ )가 필요하다. 현재 이용 가능한 $\mathrm{BFC}$ 는 방사성 표지 화학 또는 생리학적 안정성에 의해 제한점 이 있는데 3, 6, 9, 15-tetraazabicyclo [9.3.1] pentadeca-1(15), 11, 13 triene 3, 5, 9-triacetic acid(PCTA)는 1, 4, 7, 10-tetraazacyclododecane-1, 4, 7, 10-tetraacetic acid(DOTA)에 비해서 상대적으로 우수한 반응속도를 보이며 ${ }^{177} \mathrm{Lu}$ 과의 접 합체 형성에 있어서도 실온에서 5 분 미만에서 $98 \%$ 이상의 방 사화학적 purity를 보였다. 또한 PCTA는 $\mathrm{pH}$ 2 9 범위에서 효율적 접합이 되며 동물의 신장에서의 클리어런스도 ${ }^{64} \mathrm{Cu}-$ DOTA보다 ${ }^{64} \mathrm{Cu}-\mathrm{PCTA}$ 가 빠르기 때문에, 이런 여러 장점 등

Table 2. Radioisotope used in radioimmunotherapy

\begin{tabular}{lccc}
\hline \multicolumn{1}{c}{ Radioisotope } & Energymax $(\mathrm{MeV})$ & Range & Half-life \\
\hline$\beta$-particle emitter $(\mathrm{mm})$ & & & \\
${ }^{67} \mathrm{Cu}$ & 0.58 & 2.1 & $2.6 \mathrm{~d}$ \\
${ }^{90} \mathrm{Y}$ & 2.28 & 12.0 & $2.7 \mathrm{~d}$ \\
${ }^{131} \mathrm{I}$ & 0.61 & 2.0 & $8.0 \mathrm{~d}$ \\
${ }^{177} \mathrm{Lu}$ & 0.50 & 1.5 & $6.7 \mathrm{~d}$ \\
${ }^{186} \mathrm{Re}$ & 1.07 & 4.5 & $3.7 \mathrm{~d}$ \\
${ }^{188} \mathrm{Re}$ & 2.12 & 10.4 & $16.9 \mathrm{hr}$ \\
$\alpha-$ particle emitter $(\mu \mathrm{m})$ & & & \\
${ }^{211} \mathrm{At}$ & 6.8 & 80 & $7.2 \mathrm{hr}$ \\
${ }^{213} \mathrm{Bi}$ & 8.3 & 84 & $46 \mathrm{~min}$ \\
${ }^{225} \mathrm{AC}$ & $6.0-8.0$ & $60-90$ & $10.0 \mathrm{~d}$ \\
Auger-electron emitter (nm) & & \\
${ }^{125} \mathrm{n}$ & & $2-500$ & $60.5 \mathrm{~d}$ \\
\hline
\end{tabular}

Adapted from Kawashima. ScientificWorld Journal 2014;2014: 492061 ${ }^{24)} \mathrm{Cu}$ : copper, Y: yttrium, I: iodine, Lu: lutetium, Re: rhenium, At: astatine, Bi: bismuth, Ac: actinium
으로 ${ }^{177} \mathrm{Lu}-\mathrm{PCTA}$-cetuximab이 두경부암 RIT에 가장 적합 한 방사성 표지 항체 중에 하나가 될 수 있다. ${ }^{25)}$

\section{개인 맞춤형 치료로서 방사면역치료 및 Immune-PET의 역할}

방사면역치료에 사용되는 방사성 표지 항체에서 방사성 동 위원소를 영상 획득이 가능한 감마선 방출 동위원소로 치환 해서 접합을 하게 되면 면역 양전자방출단층촬영(immuno$\mathrm{PET})$ 을 이용할 수 있게 된다. Immuno-PET을 이용하게 되 면 전신에서 종양에서 발현되는 표적 항원들의 발현을 시각 화할 수 있기 때문에 침습적인 단일 생검을 통한 면역조직화 학검사와는 달리 표적 분자에 비침습적이며 정량적인 전신 이미지를 이용하여 진단 및 병기 설정을 할 때 더 포괄적인 정보를 얻을 수 있다. 병변에서의 발현 양상을 분석하여 조직 의 이질성(heterogeneity) 여부도 평가할 수 있다. 방사면역치 료와 같은 표적 치료에 있어서 표적 항원 발현의 정확한 정 량화가 가능하여 환자의 치료 적합성을 판단하여 치료 효능 을 증대시킬 수 있다. 적절한 환자가 선택된다면 약물 투여량 및 일정을 최적화하는데 도움을 받을 수 있다. 약물학적인 평가로써 표적치료제의 반응 및 표적 억제(off-target) 반응에 대한 모니터링을 할 수 있다.

수명이 긴 양전자 방출 물질인 ${ }^{124} \mathrm{I}$ 와 ${ }^{89} \operatorname{zirconium}\left({ }^{89} \mathrm{Zr}\right)$ 은 손 상되지 않은 단일클론항체와 함께 사용할 때 immune-PET에 특히 적합하다. ${ }^{26)}$

다양한 이종 이식 모델 ${ }^{27-30)}$ 에서 여러 가지 ${ }^{124} \mathrm{I}$ 표지 단일클 론항체 구조를 사용하여 뛰어난 시각화 및 정량화 결과를 얻었다. ${ }^{124} \mathrm{I}$ 표지된 단일클론항체의 PET 영상은 ${ }^{131} \mathrm{I}$ 를 방사 성 동위원소로 이용하는 RIT 이전의 치료 적합성 평가에 유 용한데 ${ }^{124} \mathrm{I}$ 및 ${ }^{131} \mathrm{I}$ 이 표지된 단일클론항체가 서로 잘 일치된 생체 분포를 나타내야 가능하며, 이는 잘 표준화된 요오드화 방법 ${ }^{31)}$ 을 통해 달성될 수 있다.

최근 두 가지 임상적 적용이 주목을 끌고 있다. Jayson 등리 은 다양한 진행성 고형 종양이 있는 12 명의 환자에서 PET 영 상 검사를 수행하기 위해 vascular endothelial growth factor $(\mathrm{VEGF})_{121}$ 과 $\mathrm{VEGF}_{165}$ 에 결합하는 단일클론항체인 ${ }^{124} \mathrm{I}-$ HuMV833을 다양하게 사용했다. 항체 분포와 클리어런스는 환자 간 및 개체 간, 종양 내외에서 현저히 이질적이었다. 이 러한 차이를 통해서 항 VEGF 단일클론항체를 이용한 치료 시에 표적의 다양성이 있음을 미리 평가할 수 있다는 의미 있는 결과를 보여주었다.

다른 임상 적용에서, ${ }^{124} \mathrm{I}$ 표지 immuno-PET는 신장암의 생 체 내 프로파일링에 사용되었다. Divgi 등 ${ }^{33)}$ 은 ${ }^{124} \mathrm{I}$ 표지 $\mathrm{c}^{-}$ 
monoclonal antibodies(mAb) G250을 사용하여 외과적 종 양 절제술을 받을 예정인 25명의 환자에서 투명세포 신장암 (clear cell renal cell carcinoma)의 존재를 확인할 수 있었다. G250은 carbonic anhydrase-IX에 대항하여 투명세포 신장 암에서 과발현된다(Fig. 2). 16 개의 투명세포암 중 15 개가 immuno-PET에 의해 정확히 확인되었고, 나머지 9개는 비투 명세포암으로 immuno-PET 검사에서 음성이었다. 이 연구는 특정 프로브를 이용한 분자 이미징이 어떻게 개인 맞춤의학에 기여할 수 있는지를 보여주었다.

또 다른 수명이 긴 양전자 방사체 ${ }^{89} \mathrm{Zr}$ 이 immuno-PET에 적용된 이후로, cetuximab, ${ }^{34)}$ ibritumomab tiuxetan, ${ }^{35)}$ rituximab, bevacizumab, ${ }^{36)}$ trastuzumab ${ }^{37)}$ 등의 다양한 단일클
론항체에 표지되어 각각의 항체에 민감한 종양 검출 및 immuno-PET를 통한 정확한 정량화가 가능함이 입증되었고, ${ }^{89} \mathrm{Zr}$ 표지 단일클론항체를 이용하는 immuno-PET는 ${ }^{90} \mathrm{Y}$ 또 는 ${ }^{177} \mathrm{Lu}$ 표지 단일클론항체를 이용한 RIT 치료 전에 생체 분포를 예측하는 데 유용한 것으로 밝혀졌다. ${ }^{34,37,38)}$ 최근에 $\mathrm{VEGF}^{32,39)}$ 및 $\mathrm{VEGF}$ receptor(VEGFR) ${ }^{40)}$ 을 표적으로 하는 immuno-PET 이미징 프로브가 개발되어서 다양하게 임상적 으로 적용이 되고 있다.

두경부 편평상피세포암(HNSCC) 환자에서 ${ }^{89} \mathrm{Zr}$ 표지 c-mAb $\mathrm{U} 36$ 을 이용한 immuno-PET의 진단적 가치를 평가하는 최 근 연구에서 ${ }^{41,42)} 20$ 명의 환자는 원발 종양 및 단측 또는 양측 목 절제술을 시행 전에 $\mathrm{CT}, \mathrm{MRI}$ 와 ${ }^{89} \mathrm{Zr}$ 표지 $\mathrm{c}-\mathrm{mAb} \mathrm{U} 36$
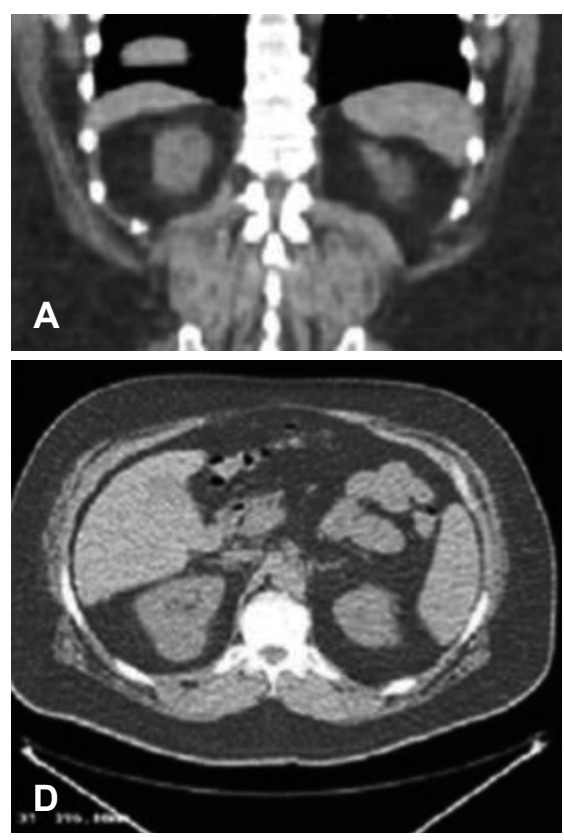

B
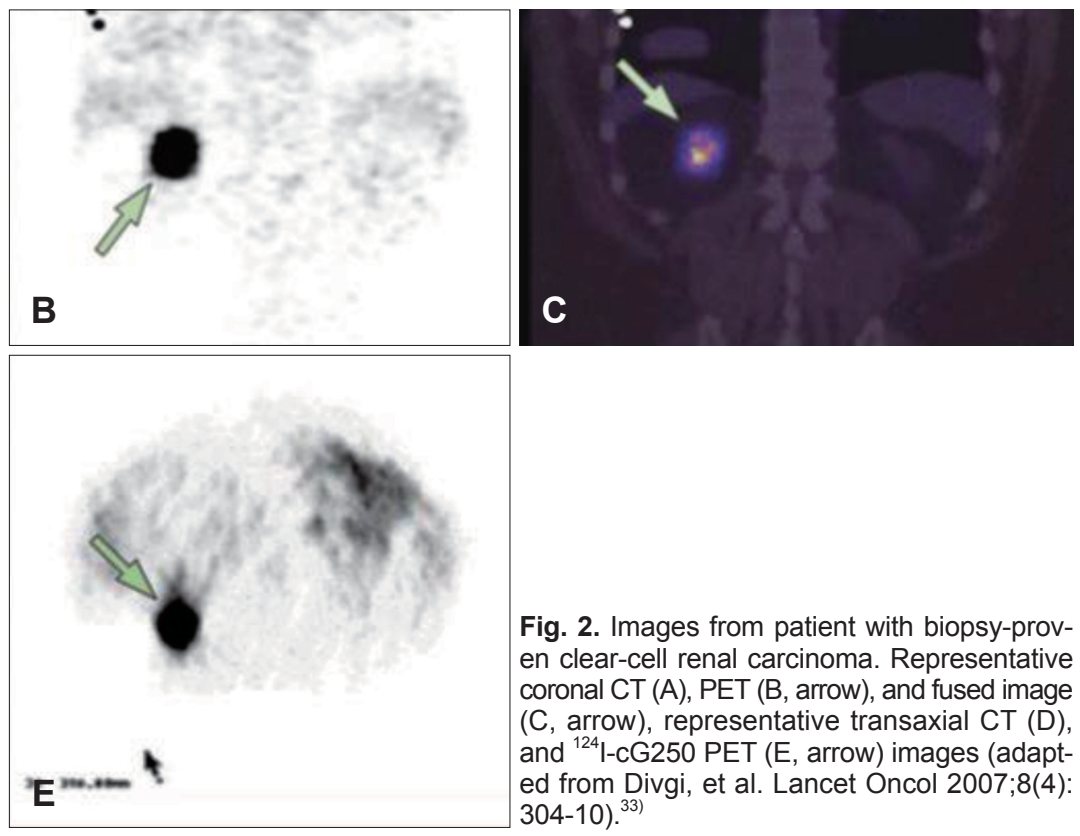

Fig. 2. Images from patient with biopsy-proven clear-cell renal carcinoma. Representative coronal CT (A), PET (B, arrow), and fused image (C, arrow), representative transaxial CT (D), and ${ }^{124}$ I-cG250 PET (E, arrow) images (adapted from Divgi, et al. Lancet Oncol 2007;8(4): 304-10). ${ }^{33)}$
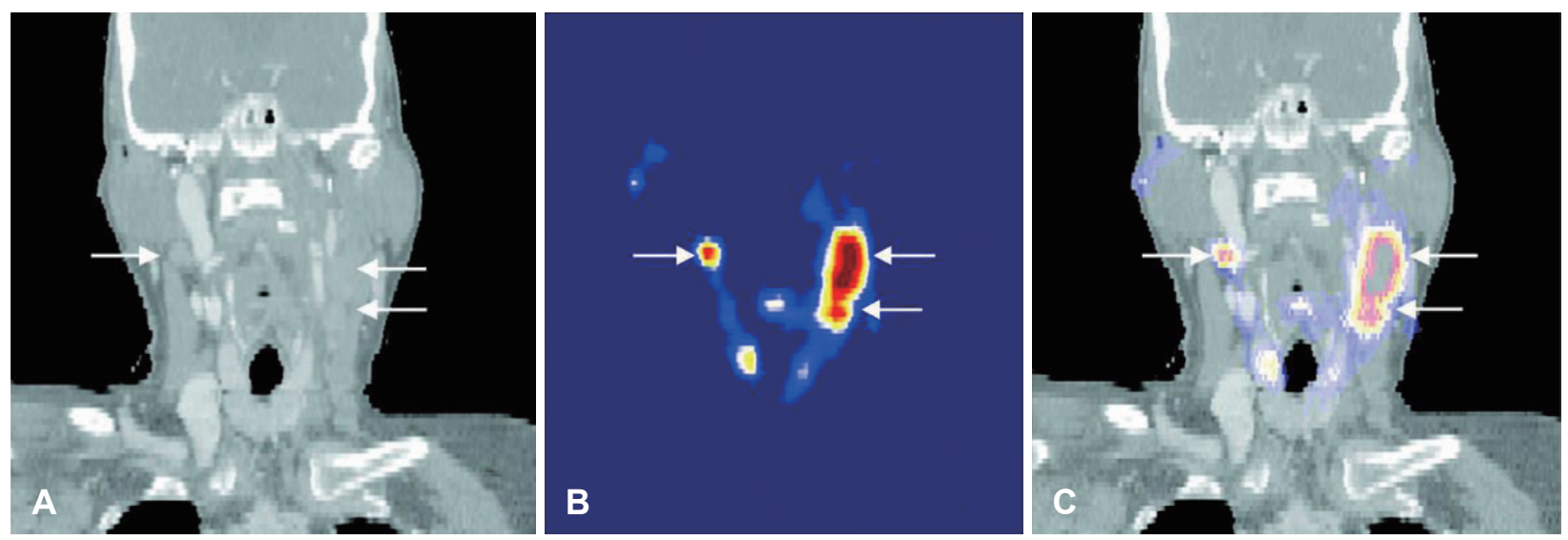

Fig. 3. Fusion (C) of CT (A) and coronal immuno-PET (B) images with the zirconium-89-labeled chimeric monoclonal antibody U36 of a head and neck cancer patient with a tumor in the left tonsil and lymph node metastases (small arrows) at the left (level II and III) and right (level II) side of the neck. Images were obtained 72 hours postinjection. In these slices, only the lymph node metastases are visible (adapted from Börjesson, et al. Clin Cancer Res 2006;12(7 Pt 1):2133-40). ${ }^{41)}$ 
immuno-PET검사를 시행 받았다. Immuno-PET에서는 모 든 원발 부위 종양 $(n=17)$ 과 25 개의 림프절 전이 중 18 개에서 양성으로 발현되었다(Fig. 3). 누락된 림프절인 경우는 크기 가 비교적 작거나 전이된 림프절 내에서 암세포의 비율이 적은 경우였다. 경부 레벨 별로 분석하였을 때, 촉진, CT/MRI, FDG $\mathrm{PET}$ 검사의 민감도(sensitivity)는 각각 $54 \%, 77 \%, 62 \%$ 였고 ${ }^{89} \mathrm{Zr}$-immuno PET는 85\%였다. 특이도(specificity)에서는 모두 $100 \%$ 를 보였다. 검사의 정확도(accuracy)는 각각 $85 \%$, $93 \%, 88 \%, 95 \%$ 를 보였다. 이 결과를 통해서 ${ }^{89} \mathrm{Zr}$ 표지 c-mAb $\mathrm{U} 36 \mathrm{immuno-PET}$ 이 HNSCC에서 림프절 전이를 진단하는 데 있어서 CT, MRI뿐만 아니라 PET-CT 검사를 보완해줄 수 있는 검사가 될 수 있음을 보여주었다.

\section{결 론}

두경부암을 포함한 고형 종양에서의 방사면역요법은 혈액 학적 악성 종양의 치료에서 의미 있는 성공률을 보였음에도 불구하고 여전히 도전 과제로 남아 있다. 방사성 동위원소가 표지되지 않은 여러 항체를 이용한 단독면역치료는 종양 성 장 신호 전달 경로를 조절하는 종양 세포 항원을 표적으로 하여 일부 성공적인 결과를 보여주고 있지만 치료 결과에 있 어서는 여전히 제한점이 존재한다. 이런 점에서 방사면역치 료가 단독면역치료의 한계를 극복하기 위한 치료적 대안이 될 수 있을 것으로 기대되며 또한 immuno-PET의 이용으로 개인 맞춤형 치료의 효과를 증대시킬 수 있을 것이다.

\section{REFERENCES}

1) Jemal A, Bray F, Center MM, Ferlay J, Ward E, Forman D. Global cancer statistics. CA Cancer J Clin 2011;61(2):69-90.

2) Dassonville O, Formento JL, Francoual M, Ramaioli A, Santini J, Schneider M, et al. Expression of epidermal growth factor receptor and survival in upper aerodigestive tract cancer. J Clin Oncol 1993; 11(10):1873-8.

3) Rubin Grandis J, Melhem MF, Gooding WE, Day R, Holst VA, Wagener MM, et al. Levels of TGF-alpha and EGFR protein in head and neck squamous cell carcinoma and patient survival. J Natl Cancer Inst 1998:90(11):824-32.

4) Soulieres D, Senzer NN, Vokes EE, Hidalgo M, Agarwala SS, Siu LL. Multicenter phase II study of erlotinib, an oral epidermal growth factor receptor tyrosine kinase inhibitor, in patients with recurrent or metastatic squamous cell cancer of the head and neck. J Clin Oncol 2004;22(1):77-85.

5) Vermorken JB, Trigo J, Hitt R, Koralewski P, Diaz-Rubio E, Rolland F, et al. Open-label, uncontrolled, multicenter phase II study to evaluate the efficacy and toxicity of cetuximab as a single agent in patients with recurrent and/or metastatic squamous cell carcinoma of the head and neck who failed to respond to platinum-based therapy. J Clin Oncol 2007;25(16):2171-7.

6) Bernier J, Bentzen SM, Vermorken JB. Molecular therapy in head and neck oncology. Nat Rev Clin Oncol 2009;6(5):266-77.

7) Boeckx C, Baay M, Wouters A, Specenier P, Vermorken JB, Peeters
M, et al. Anti-epidermal growth factor receptor therapy in head and neck squamous cell carcinoma: focus on potential molecular mechanisms of drug resistance. Oncologist 2013;18(7):850-64.

8) Niu G, Sun X, Cao Q, Courter D, Koong A, Le QT, et al. Cetuximabbased immunotherapy and radioimmunotherapy of head and neck squamous cell carcinoma. Clin Cancer Res 2010;16(7):2095-105.

9) Liu Z, Ma T, Liu H, Jin Z, Sun X, Zhao H, et al. ${ }^{177}$ Lu-labeled antibodies for EGFR-targeted SPECT/CT imaging and radioimmunotherapy in a preclinical head and neck carcinoma model. Mol Pharm 2014; 11(3):800-7.

10) Sihver W, Pietzsch J, Krause M, Baumann M, Steinbach J, Pietzsch HJ. Radiolabeled cetuximab conjugates for EGFR targeted cancer diagnostics and therapy. Pharmaceuticals (Basel) 2014;7(3):311-38.

11) Reichert JM, Valge-Archer VE. Development trends for monoclonal antibody cancer therapeutics. Nat Rev Drug Discov 2007;6(5):349-56.

12) Hatano K, Araki H, Sakai M, Kodama T, Tohyama N, Kawachi T, et al. Current status of intensity-modulated radiation therapy (IMRT). Int J Clin Oncol 2007;12(6):408-15.

13) Green N, Kern W. The clinical course and treatment results of patients with postresection locally recurrent lung cancer. Cancer 1978;42(5): 2478-82.

14) Laperriere N, Zuraw L, Cairncross G; Cancer Care Ontario Practice Guidelines Initiative Neuro-Oncology Disease Site Group. Radiotherapy for newly diagnosed malignant glioma in adults: a systematic review. Radiother Oncol 2002;64(3):259-73.

15) Dawson LA, Lawrence TS. The role of radiotherapy in the treatment of liver metastases. Cancer J 2004;10(2):139-44.

16) Sgouros G, Roeske JC, McDevitt MR, Palm S, Allen BJ, Fisher DR, et al. MIRD Pamphlet No. 22 (abridged): radiobiology and dosimetry of alpha-particle emitters for targeted radionuclide therapy. J Nucl Med 2010;51(2):311-28.

17) Song H, Sgouros G. Radioimmunotherapy of solid tumor: searching for the right target. Curr Drug Deliv 2011;8(1):26-44.

18) Van Cutsem E, Köhne CH, Hitre E, Zaluski J, Chang Chien CR, Makhson A, et al. Cetuximab and chemotherapy as initial treatment for metastatic colorectal cancer. N Engl J Med 2009;360(14):1408-17.

19) Wygoda Z, Kula D, Bierzyńska-Macyszyn G, Larysz D, Jarzab M, Właszczuk P, et al. Use of monoclonal anti-EGFR antibody in the radioimmunotherapy of malignant gliomas in the context of EGFR expression in grade III and IV tumors. Hybridoma (Larchmt) 2006; 25(3):125-32.

20) Goldenberg DM, Rossi EA, Sharkey RM, McBride WJ, Chang CH. Multifunctional antibodies by the Dock-and-Lock method for improved cancer imaging and therapy by pretargeting. J Nucl Med 2008;49(1):158-63.

21) Robert F, Ezekiel MP, Spencer SA, Meredith RF, Bonner JA, Khazaeli MB, et al. Phase I study of anti--epidermal growth factor receptor antibody cetuximab in combination with radiation therapy in patients with advanced head and neck cancer. J Clin Oncol 2001; 19(13):3234-43.

22) Dattatreya $S$, Goswami C. Cetuximab plus radiotherapy in patients with unresectable locally advanced squamous cell carcinoma of head and neck region--a open labelled single arm phase II study. Indian J Cancer 2011;48(2):154-7.

23) Huang J, Cui L, Wang F, Liu Z. PET tracers based on (86)Y. Curr Radiopharm 2011;4(2):122-30.

24) Kawashima H. Radioimmunotherapy: a specific treatment protocol for cancer by cytotoxic redioisotopes conjugated to antibodies. ScientificWorldJournal 2014;2014:492061.

25) Song IH, Noh Y, Kwon J, Jung JH, Lee BC, Kim KI, et al. ImmunoPET imaging based radioimmunotherapy in head and neck squamous cell carcinoma model. Oncotarget 2017;8(54):92090-105.

26) Verel I, Visser GW, Boerman OC, van Eerd JE, Finn R, Boellaard R, et al. Long-lived positron emitters zirconium- 89 and iodine-124 for 
scouting of therapeutic radioimmunoconjugates with PET. Cancer Biother Radiopharm 2003;18(4):655-61.

27) Lee FT, Hall C, Rigopoulos A, Zweit J, Pathmaraj K, O’Keefe GJ, et al. Immuno-PET of human colon xenograft-bearing BALB/c nude mice using ${ }^{124}$ I-CDR-grafted humanized A33 monoclonal antibody. J Nucl Med 2001;42(5):764-9.

28) Sundaresan G, Yazaki PJ, Shively JE, Finn RD, Larson SM, Raubitschek AA, et al. ${ }^{124}$ I-labeled engineered anti-CEA minibodies and diabodies allow high-contrast, antigen-specific small-animal PET imaging of xenografts in athymic mice. J Nucl Med 2003;44(12):1962-9.

29) Jain M, Batra S. Genetically engineered antibody fragments and PET imaging: a new era of radioimmunodiagnosis. J Nucl Med 2003;44 (12):1970-2.

30) Robinson MK, Doss M, Shaller C, Narayanan D, Marks JD, Adler LP, et al. Quantitative immuno-positron emission tomography imaging of HER2-positive tumor xenografts with an iodine-124 labeled anti-HER2 diabody. Cancer Res 2005;65(4):1471-8.

31) Verel I, Visser GW, Vosjan MJ, Finn R, Boellaard R, van Dongen GA. High quality ${ }^{124}$ I-labelled monoclonal antibodies for use as PET scouting agents prior to ${ }^{131}$ I-radioimmunotherapy. Eur J Nucl Med Mol Imaging 2004;31(12):1645-52.

32) Jayson GC, Zweit J, Jackson A, Mulatero C, Julyan P, Ranson M, et al. Molecular imaging and biological evaluation of HuMV833 antiVEGF antibody: implications for trial design of antiangiogenic antibodies. J Natl Cancer Inst 2002;94(19):1484-93.

33) Divgi CR, Pandit-Taskar N, Jungbluth AA, Reuter VE, Gönen M, Ruan $\mathrm{S}$, et al. Preoperative characterisation of clear-cell renal carcinoma using iodine-124-labelled antibody chimeric G250 $\left({ }^{124} \mathrm{I}-\mathrm{cG} 250\right)$ and PET in patients with renal masses: a phase I trial. Lancet Oncol 2007; 8(4):304-10.

34) Perk LR, Visser GW, Vosjan MJ, Stigter-van Walsum M, Tijink BM, Leemans CR, et al. (89)Zr as a PET surrogate radioisotope for scouting biodistribution of the therapeutic radiometals $(90) \mathrm{Y}$ and (177)Lu in tumor-bearing nude mice after coupling to the internalizing antibody cetuximab. J Nucl Med 2005;46(11):1898-906.

35) Perk LR, Visser OJ, Stigter-van Walsum M, Vosjan MJ, Visser GW, Zijlstra JM, et al. Preparation and evaluation of (89)Zr-Zevalin for monitoring of (90)Y-Zevalin biodistribution with positron emission tomography. Eur J Nucl Med Mol Imaging 2006;33(11):1337-45.

36) Nagengast WB, de Vries EG, Hospers GA, Mulder NH, de Jong JR, Hollema $\mathrm{H}$, et al. In vivo VEGF imaging with radiolabeled bevacizumab in a human ovarian tumor xenograft. J Nucl Med 2007;48(8):1313-9.

37) Dijkers E, Lub-de Hooge MN, Kosterink JG, Jager PL, Brouwers $\mathrm{AH}$, Perk LR, et al. Characterization of ${ }^{89} \mathrm{Zr}$-trastuzumab for clinical HER2 immunoPET imaging. J Clin Oncol 2007;25(suppl 18):3508.

38) Verel I, Visser GW, Boellaard R, Boerman OC, van Eerd J, Snow GB, et al. Quantitative ${ }^{89} \mathrm{Zr}$ immuno-PET for in vivo scouting of ${ }^{90} \mathrm{Y}$-labeled monoclonal antibodies in xenograft-bearing nude mice. J Nucl Med 2003;44(10):1663-70.

39) Collingridge DR, Carroll VA, Glaser M, Aboagye EO, Osman S, Hutchinson OC, et al. The development of [(124)I]iodinated-VG76e: a novel tracer for imaging vascular endothelial growth factor in vivo using positron emission tomography. Cancer Res 2002;62(20): 5912-9.

40) Cai W, Chen K, Mohamedali KA, Cao Q, Gambhir SS, Rosenblum $\mathrm{MG}$, et al. PET of vascular endothelial growth factor receptor expression. J Nucl Med 2006;47(12):2048-56.

41) Börjesson PK, Jauw YW, Boellaard R, de Bree R, Comans EF, Roos $\mathrm{JC}$, et al. Performance of immuno-positron emission tomography with zirconium-89-labeled chimeric monoclonal antibody U36 in the detection of lymph node metastases in head and neck cancer patients. Clin Cancer Res 2006;12(7 Pt 1):2133-40.

42) Zalutsky MR. Potential of immuno-positron emission tomography for tumor imaging and immunotherapy planning. Clin Cancer Res 2006;12(7 Pt 1):1958-60.

\section{정답 및 해설}

1. 답 (3)

해 설 구강 점막의 소견 상에서 erosive lichen planus 혹은 erythroplakia가 의심되는 상태로 악성 변화를 확인하기 위해 우 선적으로 조직 검사를 시행해야 한다.

2. 답 (4)

점액낭종(mucocele)이 의심되는 상태로 봉합술(suture technique), 조대술(marsupialization), 혹은 경구강 절제술 (excision)을 시행해 볼 수 있다. 